\section{Plant Hormone Investigations}

A sTuDY meeting on the subject of "Phytohormones" was held at the International Institute of Intellectual Co-operation on October 1 and 2 . This meeting, which was organized by the International Institute of Intellectual Co-operation and the International Union of Biological Sciences, was the first of a series that will be held in the course of the coming months and which will discuss a variety of questions such as "The New Vitamins", "Nomenclature of Genetics", "The Double Electric Layer", etc., included in the plan of work of the International Council of Scientific Unions, which acts as a committee of scientific advisers to the Intellectual Co-operation Organization. The meeting was held under the chairmanship of Prof. P. Boysen Jensen and reports were discussed on various aspects of the study of phytohormones, prepared by the following: Prof. F. Kögl, Utrecht; Prof. Niels Nielsen; Prof. N. J. Koningsberger, Utrecht; Prof. G. S. Avery, Connecticut; Prof. R. Bouillenne, Liége; Prof. C. Zollikofer, Zurich ; Prof. K. Dostal, Brmo ; and nomenclature of phytohormones, by Dr. Janot, Paris. The question of the nomenclature of phytohormones gave rise to an exhaustive discussion and positive results have been reached. The reports and the discussions to which they gave rise will be published under the auspices of the International Institute of Intellectual Cooperation and the International Union of Biological Sciences. This publication will be revised by Prof. Boysen Jensen before being issued. The second meeting of this character will be held at Copenhagen at the end of September 1939. Profs. Boysen Jensen, Laibach and Koningsberger have been invited to organize this meeting from the technical point of view, in collaboration with the International Union of Biological Sciences.

\section{Archæological Investigations in Ireland}

Archalological excavations continue to be carried on with vigour in Ireland through the scheme for the relief of unemployment under the direction of the Office of Public Works and the National Museum. Among the more important of recent discoveries are the antiquities brought to light in the excavation of the large ring fort at Garranes, near Templetown, Co. Cork, which throw a valuable light on the industries and culture of the little-known period of the sixth century of our era. The excavations are being conducted by Prof. Sean P. O'Riordain, professor of archæology in University College, Cork. The site is identified with Rath Raithleann. The fort has triple ramparts, with an external diameter of about three hundred feet. The entrance proved on excavation, according to a report in The Times of October 18, to be of a complex character, with several gates, of which the fourth and last in the approach to the interior was formed by rows of posts, small tree trunks of six inches in diameter, set in two palisade trenches terminating the middle bank at each side of the opening.
IN the inner bank of the fort under masses of stone, which had been used to strengthen it, was a deposit showing that here had been the workshop of the metal-workers, who had been under the patronage of the ruler. Clay crucibles were found here in greater number than had previously been found in the whole of Ireland. Some still contained the bronze they had been used to melt, while others, of a type previously known from Scotland, but not hitherto found in Ireland, had been used to melt enamel. A discovery of extreme interest consisted of pieces of millefiori glass, made by fusing different coloured pieces of glass together, which leave no room for doubt that the millefiori glass of Irish ornament was a native product. Another important discovery was a quantity of pottery fragments, of which some are Roman, while others are copies. Such pottery has hitherto been lacking from Irish fifth and sixth century sites.

\section{The Battersea Power Station}

THE annual report of the Electricity Commissioners (London : H.M. Stationery Office) giving the returns of fuel consumption and electric units generated in Great Britain shows that the total quantity of electricity generated during 1936 was 14 per cent more than during the preceding year. The annual fuel consumption was $\mathbf{1} \cdot \mathbf{5 7} \mathbf{l b}$. per electric unit distributed. The steam station with the highest thermal efficiency, 27.63 per cent, is Battersea (London Power Company) and the station with the highest load, 208,000 kilowatts, is Barking A (County of London). The London Power Co. is extending its station at a cost of $£ 1,500,000$. The work constitutes the beginning of the second half of the station and includes the extension of the building to double its present size and the installation of $100,000 \mathrm{kw}$. of generating plant. This is the first instalment of the plant to be provided in the new building. It is expected that this, together with the $243,000 \mathrm{kw}$. plant already working, will meet the probable demands for electricity up to the winter 1939-40. Eventually the generating capacity is to be raised to $500,000 \mathrm{kw}$. The new plant comprises a high-pressure set, a low-pressure set and a house set. The high-pressure set generates $16,000 \mathrm{kw}$, the low-pressure set $78,000 \mathrm{kw}$. and the house set $6,000 \mathrm{kw}$. The new plant also includes one boiler of $550,000 \mathrm{lb}$. evaporative capacity. Londoners will watch the development of this huge power station with interest. Practice has justified the policy of fostering the efficient stations in Great Britain. The returns show that whilst there were 458 generating stations in 1935 , there were only 442 in 1936 .

\section{Loris: a Journal of Ceylon Wild Life}

IN many respects the fauna of Ceylon is of unusual interest, and like many another island fauna it runs the risk of gradual encroachments at the hands of 'civilized' man. In order to further the preservation of the native animals and to stimulate a greater interest in them and their habits, the Ceylon Game and Fauna Protection Society has undertaken the 
publication of a new natural history magazine, Loris, to be issued twice a year (Colombo and London : Times of Ceylon Co., Ltd. 2s. 6d.). That there is need for such propaganda is shown by the history of faunal protection in Ceylon, which A. B. Lushington contributes to the first number. The slaughter of sambhur and deer for the sake of the export of their hides and horns had reached gigantic proportions and entailed great cruelty, before the Government in $\mathbf{1 8 9 1}$ passed ordinances to check the trade and to "prevent the wanton destruction of elephants, buffaloes and other game". Even so the trade continued, and several subsequent enactments have been required to bring about the protection which was desired. The first number of Loris is by no means confined to direct propaganda, for the editors are aware that the stimulation of interest in animal life is a better means to their end than mere denunciation. Accordingly they include sporting articles of a naturalist flavour, accounts of trips in the jungle, and an instructive article on natural history photography and the apparatus it demands, illustrated by excellent photographs of birds and nests.

\section{Fisheries of Wales}

A TEMPORARY exhibition illustrating the activities of the Welsh fishing industry has been on view during the past five months at the National Museum of Wales. A small hand-book supplements the information given on the labels of the exhibits ("The Fisheries of Wales". By Colin Matheson. National Museum of Wales and the Press Board of the University of Wales. 2d.). The fishes landed in the largest quantities in Wales are demonstrated by models and spirit specimens, and the handbook sets forth the habitats and means of capture of the different species, with some comments on their biology. The hake, on which the deep-sea fisheries of South Wales are based, is given due prominence. A separate section is given to the deep-water trawler and its methods of work, with exhibits of echo-sounding devices and wireless direction-finders. The beam trawl and various appliances of the inshore fisherman are explained; and there are notes upon the primitive Welsh coracle and the salmon nets and spears used in fresh water. The general ignorance about the modern fishing industry is so great that a welcome must be extended to such an exhibition as this, for it will show that each species of fish must be sought by methods adapted to its habitat and habits; and that every fishing boat more than 20 feet long is not necessarily a trawler. Mr. Matheson is to be congratulated upon the arrangement of such a demonstration.

\section{British Association Seismological Committee}

THE recent report of the Committee of Seismological Investigations records much useful work done by its members. During the preceding year, three slight earthquakes occurred in the British Isles: in East Kent on December 29, 1936, in North Staffordshire on April 7, 1937, and near Inverness on June 26, 1937. Brief references are made to the study of the recent earthquakes in Montserrat, to Mr. Brennan's work on the greater frequency of earthquakes in Jamaica during the dry months of the year, to the deep-focus earthquakes of 1932, and to the new globe, 18 in. in diameter, recently installed at Oxford, which has already proved most useful in the determination of epicentres. Notes are also contributed by Dr. H. Jeffreys on seismic transmission times, and by Dr. R. Stoneley on his study of the records of the Mongolian earthquake of August 10, 1931.

\section{Parliamentary Science Committee}

The Right Hon. J. Ramsay MacDonald has recently accepted an invitation to join the executive of the Parliamentary Science Committee. It has always been the aim of the Committee to preserve an even balance between men of science and Parliamentarians on the executive, and on the Parliamentary side to secure representatives from all political parties. Mr. MacDonald's advent brings the Parliamentarians up to eleven-three peers, and eight members of the House of Commons. The three peers are the Earl of Dudley (president), Lord Melchett and Lord Rothschild. The members of the lower house are Sir Arnold Wilson (chairman), Mr. Alan Chorlton (deputy-chairman), Mr. Ramsay MacDonald, Prof. J. Graham Kerr, Sir Philip Dawson, Sir Murdoch MacDonald, Mr. Andrew MacLaren, and Mr. S. F. Markham.

\section{Komodo 'Dragons' at Edinburgh Zoological Park}

BY permission of the Netherlands Government, two Komodo monitors (Varanus komodoensis) have been added to the collections at the Scottish National Zoological Park in Edinburgh. This gigantic lizard, which may reach a length of 10 feet, was first shown in Great Britain at the London Zoo in 1927, a year after the habits of the creature had been studied by an American expedition in its native island of Komodo to the south-east of Java. It is swift and active out of keeping with its heavy build, and is said to be fierce as well as voracious, the larger individuals feeding when opportunity offers upon deer and wild pigs.

\section{The Joint Committee on Materials and Their Testing}

THE Joint Committee, whic consists of representatives of twenty-four co-operating technical institutions and societies under the chairmanship of Dr. H. J. Gough, has arranged its first technical discussion to take place in the College of Technology, Manchester, on October 29, commencing at 2.30 p.m., when a series of three important papers on different aspects of "Notched Bar Impact Testing" will be presented. Application forms for papers and reprints, and for tickets to attend, should be made to the Secretary, the Manchester Association of Engineers, St. John Street Chambers, Deansgate, Manchester, 3. Particulars regarding the objects, aims and work of the Joint Committee may be obtained from the Secretary, Joint Committee on Materials and their Testing, at the Institution of Mechanical Engineers, Storey's Gate, Westminster, London, S.W.1. 